rozboru transferu informací a verbální i symbolické komunikace. Stranou nezůstalo ani patrné propojování intelektuálních dějin s novými politickými dějinami v otázkách distribuce moci v rámci vztahu město - univerzita, či teorií sociálních sítí v př́ípadě akademické peregrinace a budování osobních vazeb mezi členy univerzit a městských obcí. V neposlední řadě byl patrný odklon od dřivějš̌́ho jednostranného studia konfliktního potenciálu ve vztahu město vs. univerzita ve prospěch hlubších analýz, které se zabývají ekonomickou, právní a společenskou kooperací a vzájemnou prospěšností těchto dvou institucí.

Josef Kadeř́ábek

doi: $10.14712 / 23365730.2018 .14$

\title{
Zpráva o pracovním pobytu ve Výzkumném ústavu pro východní Evropu př̀ Univerzitě v Brémách (Forschungsstelle Osteuropa an der Universität Bremen), 20. 2. - 3. 3. 2017
}

Podnětem k uskutečnění pobytu ve Výzkumném ústavu pro východní Evropu při Univerzitě v Brémách bylo setkání s paní Mgr. Karinou Garszteckou z Výzkumného ústavu pro východní Evropu při Univerzitě v Brémách, která navštívila Archiv Univerzity Karlovy v rámci své studijní cesty na konci srpna 2016.

První myšlenka na založení výzkumného ústavu v Brémách je př́́mo spjata se vznikem Charty 77. Ještě v tom samém roce navrhl bývalý ředitel Československé televize a poslanec italských socialistů v Evropském parlamentu Jiří Pelikán v rozhovoru s bývalým německým kancléřem Willy Brandtem založení vědeckého ústavu, který by shromažd’oval a vyhodnocoval dokumenty občanských hnutí. Willy Brandt poté s touto myšlenkou obeznámil zemské ministerské předsedy a ti ji delegovali dále. Právě tehdejší starosta Brém Hans Koschnick byl toho názoru, že by pracoviště, které se angažuje ve prospěch lidských práv a svobodného projevu, bylo vhodné přičlenit $\mathrm{k}$ nově založené Brémské univerzitě. Cesta $\mathrm{k}$ takovému úkolu nebyla ovšem jednoduchá, nebot' v roce 1980 došlo k zhoršení mezinárodních vztahů (např. válka v Afghánistánu). Objevily se také obavy, že založení takového ústavu by mohlo narušit snahy o bezpečnost a uvolnění mezi Západem a zeměmi sovětského bloku. Projekt však na naléhání několika významných německých intelektuálů pokračoval dál, a tak Výzkumný ústav pro východní Evropu 3. května 1982 oficiálně zahájil svou činnost. Jeho vedení se ujal vedoucí katedry pro soudobé dějiny a východoevropskou politiku prof. Dr. Wolfgang Eichwede. ${ }^{1}$ Od roku 2008 do současnosti je ředitelkou ústavu profesorka východoevropských dějin Susanne Schattenberg.

Od svého založení dodnes shromažd’uje ústav jedinečné prameny k soudobým a kulturním dějinám východní Evropy od roku 1953 do současnosti. ${ }^{2}$ Jeho jádro tvoří specifické, avšak členité spektrum materiáli̊, které mu v souhrnu propůjčují svébytný profil: 1. dokumenty samizdatu od padesátých let do konce 80 . let; 2 . neformální tiskoviny a dokumenty

1 Wolfgang Eichwede (Hg.), Das Archiv der Forschungsstelle Osteuropa. Bestände im Überblick: UdSSR/Russland, Polen, Tschechoslowakei, Ungarn und DDR, Stuttgart 2009, s. 15.

2 Die Forschungstelle (online). Dostupné na $<$ http://www.forschungsstelle.uni-bremen.de/de/2/20110606110855 /Die_Forschungsstelle.html> (12.5.2017). 
dokládající porevoluční transformaci; 3. pozůstalosti, zejména z Ruska, Sovětského svazu a ruské emigrace, které zahrnují celé 20. století. ${ }^{3}$

Činnost ústavu zasahuje do čtyř oblastí - výzkum, ${ }^{4}$ archiv ${ }^{5}$ a knihovna, ${ }^{6}$ analýzy aktuálního dění v konkrétních východoevropských státech ${ }^{7}$ a výstavní činnost. ${ }^{8}$

Paní Mgr. Garsztecká má v domovském pracovišti na starosti oblast archivu - dokumenty oddělení středovýchodní Evropy a knihovnu polského a českého samizdatu, kde jsou samozřejmě zastoupeny také materiály československé provenience. Tematicky je lze rozdělit do následujících oblastí: Charta 77, náboženská, ekologická a mírová hnutí, další neformální hnutí a skupiny, periodika, audiovizuální média, literatura, výtvarné umění, undergroundová hnutí, Jazzová sekce a věda. ${ }^{9}$

Knihovna českého samizdatu představuje jednu z největších sbírek samizdatových publikací. Obsahuje zhruba 1000 monografií a sborníků a 120 periodik a stovky takzvaných drobných tisků. Zahrnuje napřr. 386 svazků edice Petlice. Dále můžeme v tomto oddělení nalézt umělecké předměty, plakáty, fotografie, zvukové pásky a videosestřihy. Z archivních pramenů jmenujme pozůstalost fotografa Ivana Kyncla (1953-2004), jejíž jádro tvoří zejména fotografie a negativy, pozůstalost básníka, esejisty a výtvarníka Karla Trinkewitze (1931-2014), novináře a politika Jiřího Pelikána (1923-1999) nebo básníka a diplomata Jiř́iho Gruši (1938-2011). Za zmínku stojí také dokumenty Jazzové sekce (rozbor fondu viz níže), které byly představeny na konci roku 2016 a začátkem roku 2017 na putovní výstavě „Složité hledání rovnováhy - Jazzová sekce, moderní umění a hudba v Československu“, která se konala v Praze, Brémách a Bratislavě. ${ }^{10} \mathrm{~V}$ oddělení středovýchodní Evropy jsou uloženy také dokumenty mad'arského a hlavně polského samizdatu. Vedle písemností z fondů odborového svazu Solidarity zde nalézáme např. edice nakladatelství Most nebo samizdatové poštovní známky.

V druhém oddělení archivu, zahrnujícím oblast Ruska a bývalého SSSR, je vedle samizdatových publikací a jiných dokumentů uloženo okolo 600 osobních archivů, mezi nimiž se nacházejí fondy spisovatelů Lva Kopeleva (1912-1997), Jurije Trifonova (1925-1981) či filozofa Borise Groyse (nar. 1947). K pozoruhodným archiváliím tu bezesporu patří samizdatová verze novely Alexandra Solženicyna Jeden den v životě Ivana Denisoviče, která byla sice po schválení ÚV KSSS uveřejněna v roce 1962 v časopise Novyj Mir, ale po nějaké době byla opět zakázána a vydána jako samizdat. Badatel se v archivu může seznámit také s některými méně známými dobovými souvislostmi a informacemi, jako je význam

3 W. Eichwede (Hg.), Das Archiv der Forschungsstelle Osteuropa, s. 18.

4 Výzkumná činnost se člení na dvě pracovní oblasti, které jsou dále děleny podle jednotlivých států: historii a kulturu, politiku a hospodářství. Stěžejními zeměmi, kterými se výzkumný ústav zabývá, jsou země bývalého Sovětského svazu respektive Rusko, Ukrajina, střední Asie a země středoevropské, především Polsko a Česko.

5 Badatelsky př́stupné dokumenty se nacházejí v online katalogu. Dostupný na <http://134.102.235.4:9090 /aDISWeb/app?service=direct/0/Home/\$DirectLink $\$ 1 \&$ sp=S134.102.235.4\%3A420> (12. 5. 2017).

6 Katalog dostupný na $<$ http://vzlbs2.gbv.de/DB=71/LNG=DU/> (12. 5. 2017).

7 Dostupné na <http://www.laender-analysen.de/> (12. 5. 2017). Tyto analýzy umožňují online formou pravidelně a kompetentně hodnotit aktuální politické, vědecké, sociální a kulturní události či změny ve východní Evropě a SNS. Znalosti, získávané prostřednictvím vědeckého výzkumu a týkající se politiky a ekonomie, se touto cestou zpř́ístupňují zájemcům v médiích a širší veřejnosti. Autory jsou mezinárodně činní vědci a odborníci z př́islušných oborů.

8 Jedná se o větší či menší výstavy z fondů ústavu nebo o zápůjčky dalším institucím.

9 W. Eichwede (Hg.), Das Archiv der Forschungsstelle Osteuropa, s. 118.

10 Dvojjazyčný katalog k výstavě: Martina WINKLER - Rüdiger RitTER, Ein schmaler Grat - die Jazz-Sektion, zeitgenössische Kunst und Musik in der Tschechoslowakei, Bremen 2016. 
pojmů „kassiba“ (pašované mini lístečky popisující poměry ve vězení) nebo „magnitzdat“ (LP desky zakázaných ruských písničkářù ,vyražené“ na rentgenových snímcích).

Archivní fondy jsou uloženy v klimatizovaném depozitáři s posuvnými regály. Samotná budova výzkumného ústavu byla postavena v roce 1997 a má tři patra. V dolním patře sídlí správa budov a zařízení, výzkumný ústav pak ve druhém (kde se kromě depozitářu nacházejí kanceláře a pořádací místnosti) a třetím patře (kde je umístěna odborná knihovna, badatelna a kanceláře externích pracovníků a sekretariátu). Kromě dvou výše zmíněných pracovnic zajišt’ují činnost ústavu další vědečtí pracovníci a pomocné vědecké síly z řad studentů. V budově se nalézá také kancelář prof. Martiny Winkler, která se zabývá kulturními dějinami východní Evropy se zaměřením na Československo. Její disertace o Karlu Kramářovi vyšla v nakladatelství Argo v roce 2011.

Nedaleký univerzitní archiv v Brémách ${ }^{11}$ pod vedením paní Sigrid Dauks uchovává a zpř́istupňuje archiválie pocházející z činnosti Brémské univerzity, jež vznikla v roce 1971 jako tzv. reformní univerzita. Jejím cílem bylo pokusit se propojit různé vědní disciplíny, např. humanitní obory, se sociálními vědami. Univerzita byla sice plánována s klasickými obory jako právo, medicína a př́rodní vědy, avšak s interdisciplinární dimenzí (tzv. projektové studium). Běžný název ,fakulta“ byl z těchto důvodů nahrazen názvem ,vědní oblast“ (Fachbereich). V současnosti existuje dvanáct „vědních oblastíi“, na kterých studuje kolem 20000 studentů. Je zajímavé, že k založení lékařské fakulty nakonec vůbec nedošlo. Univerzita je rovněž několika svými pracovišti zapojena do iniciativy „Excellence“ (program státní podpory poskytované vybraným univerzitním pracovištím s nejlepšími výsledky ve vědě a výzkumu). Vyjádřením interdisciplinárního propojení je také rozsáhlý univerzitní kampus, kde se nacházejí i mimouniverzitní instituce, jež však s univerzitou úzce spolupracují, např. Max-Planck-Institut v oblasti mořské mikrobiologie nebo Frauenhofer-Institut v oblasti materiálového inženýrství.

Archiv vznikl až v červnu roku 2000, do současné budovy z počátku 70. let 20. století se přestěhoval v roce 2010. Vzhledem k tomu, že se jedná o „mladou“ univerzitu, uchovává archiv zatím pouze 800 běžných metrů archiválií (bez depozit), které jsou většinou archivně zpracovány, k čemuž je využíván archivní program Faust. Na podzim 2017 dojde k online zpř́stupnění databáze pro vyhledávání archiválií. Co se týká struktury archiválií, jádrem archivu jsou písemnosti vzešlé z činnosti rektora a materiály zahrnující vědu a výzkum, dále se zde nacházejí písemnosti akademického senátu, kateder, institutů, osobní složky zaměstnanců a další dokumenty. ${ }^{12}$ Personální spisy studentů nejsou zatím do archivu předávány, nebot' mají dlouhé skartační lhůty (40 let). Z hlediska zkušeností z pražského univerzitního archivu je zajímavé srovnání způsobu, jakým je v Brémách nakládáno s kvalifikačními pracemi. Skartační řízení probíhá každé dva roky. Do archivu jsou však předávány pouze vzorky bakalářských prací a těch, které dokumentují dějiny regionu. Diplomové práce jsou předávány všechny. Kvalifikační práce jsou zpřístupňovány po obhajobě a se souhlasem autora, a to $v$ tištěné podobě.

Aby byl přehled fondů úplný, je nutno zmínit také významnou část archivu, a to depozita písemností Nadace pro sociální dějiny (Archiv der Stiftung für Sozialgeschichte), které byly do univerzitního archivu předány v roce 2014. Jedná se o sbírky pramenů a materiálů

11 Universitätsarchiv (online). Dostupné na <http://www.uni-bremen.de/archiv.html $>$ (12. 5. 2017).

12 Bestände (online). Dostupné na <http://www.uni-bremen.de/archiv/bestaende.html > (12. 5. 2017). 
o rozsahu 450 běžných metrů, které vznikly v souvislosti s badatelskými a edičními projekty Nadace, obzvláště $\mathrm{k}$ tématům světové hospodářské krize, období nacismu a studené války. ${ }^{13}$

Pominout nelze ani pozoruhodnou sbírku plakátů. O soubor zhruba 1800 kusů plakátů od roku 1971 do současnosti, který je důležitým pramenem k sociálnímu hnutí studentstva, se stará pan Thomas Lietz. Digitalizováno je zatím 1300 plakátů. Po vyřešení problémů s autorskými právy (některé plakáty vyrobily studentské skupiny či jednotlivci, jejichž autorství se těžko dohledává), budou zveřejněny on-line.

Během čtrnáctidenního studijního pobytu ve Výzkumném ústavu pro východní Evropu jsem se věnoval pořádání fondu Jazzové sekce Svazu hudebníků.

Jazzová sekce vznikla v roce 1971 jako zájmové kulturní sdružení působící především na poli propagace jazzové hudby (pořádání koncertů), vydávala také informační materiály pro své členy (např. bulletin Jazz), postupně začala propagovat i jiné hudební směry (zejména rock) a v rámci edice Jazz-Petit vydávat další texty (např. román B. Hrabala Obsluhoval jsem anglického krále), které již nekolovaly pouze mezi členy. Komunistický režim se pokoušel této činnosti zamezit různými zákazy. Ty však nebyly akceptovány a Jazzová sekce byla roku 1984 rozpuštěna. Vedení Jazzové sekce tento zákaz nerespektovalo a v nakladatelské činnosti pokračovalo dál. Vše skončilo soudem v roce 1987, kdy vedoucí činitelé Jazzové sekce (Karel Srp, Vladimír Kouřil, Čestmír Huňát, Tomáš Křivánek a Joska Skalník) dostali několikaměsíční, př́ípadně podmíněné tresty za nedovolené podnikání. Činnost Jazzové sekce pokračuje v rámci sdružení Artforum a Unijazz dodnes.

Fond samotný obsahuje stanovy, zprávy o činnosti, zápisy ze schůzí, hospodářské záležitosti, korespondenci, publikace a časopisy z vlastní nakladatelské činnosti, dokumenty ze soudního ř́zení v letech 1986-1987, fotografie a materiály cizích osob (katalogy k výstavám různých umělců). Fond byl do výzkumného centra předán Karlem Srpem v letech 2002 a 2004, protože podle jeho slov o něj nebyl ze strany českých institucí zájem. ${ }^{14}$ V této souvislosti je nutno ovšem zmínit, že další část archivu Jazzové sekce se nachází v Národním archivu v Praze..$^{15} \mathrm{I}$ když byl fond již dříve částečně uspořádán, nebylo možné pořádání z důvodu kratší časové dotace, než bylo původně plánováno (čtyři týdny), dokončit $\mathrm{v}$ úplnosti. Nezbývá než doufat, že $\mathrm{v}$ dohledné době se zpracování a zpř́stupnění fondu podaří dovést ke zdárnému konci, nebot' se jedná o důležitý pramen pro dějiny alternativních spolků v normalizačním Československu.

Michal Továrek

doi: $10.14712 / 23365730.2018 .15$

13 Archiv der Stiftung für Sozialgeschichte (online). Dostupné na $<$ http://www.uni-bremen.de/archiv/archiv-der -stiftung-fuer-sozialgeschichte.html> (12. 5. 2017).

14 Viz deník Právo, 2. 5. 2002.

15 Národní archiv, Jazzová sekce (1968-1998). Fond vznikl sbírkovou činností Karla Mašity, který byl v 90. letech 20. století právním zmocněncem nástupnické organizace Jazzové sekce - Artfóra. 